\title{
BIRDS OF THE QU'APPELLE- SECOND SUPPLEMENT
}

\author{
RONALD R. HOOPER, Box 757, Ft. Qu'Appelle, SK S0G 1S0
}

Manley Callin's "Birds of the Qu'Appelle", published in 1980, reported 287 species in the vicinity of the Qu'Appelle Valley from just west of Pasqua Lake to the Manitoba border. ${ }^{2}$ Manley continued to keep records and after his death Stuart and Mary Houston compiled "Additions to Callin's Birds of the Qu'Appelle", which was published in 1986. ${ }^{5}$ This supplement brought the total number of species for the area to 298. Splitting the towhees into two species made it into 299. There were, in addition, 5 hypothetical species.

The members of the Fort Qu'Appelle Branch of Nature Saskatchewan (of which Manley was an active member); have continued to keep track of important records in the Fort Qu'Appelle area. John Pollock has been avidly watching and banding birds in the Whitewood and Round Lake areas, and has submitted some excellent records from the east end of the valley. Boyd Metzler, who annually travels the eastern part of the Qu'Appelle River by canoe, also gave some good records. Additional records came from Robert Kreba of Regina, who went birding in the area quite often. Other records were gleaned from the Christmas Bird Count reports in Blue Jay.

The following list adds 11 confirmed species, bringing the total to 310 . Three hypothetical species were added: Black Vulture, Black-chinned Hummingbird and Carolina Wren. Three of the previous unconfirmed species are still hypothetical: Iceland Gull, Red-shouldered Hawk and Swallowtail Kite. The only additional breeding records are for Turkey Vulture and Common Raven. 295 of the species have been recorded within $25 \mathrm{~km}$ of Fort Qu'Appelle. In many cases there are earlier or later dates than previously published. There are also some changes concerning the increase or decrease of some species.

Records from December to February are called winter records. Many are species attempting to winter that often don't make it through until spring; some are injured birds unable to migrate.

Abbreviations used -* Hypothetical species (still unconfirmed for Saskatchewan). -\# New species for the area. -BM Boyd Metzler. -CBC Seen on a Christmas Bird Count. -JM Jean McKenna. -JP John Pollock. -LR Lorne Rowell. -ML Maurice Lindgren. -PA Peter Ashcroft. -PB Phyllis Bordass. -RH Ronald Hooper. -RK Robert Kreba.

The arrangement of species is according to that used in Manley Callin's book, "Birds of the Qu'Appelle". Common names comply with those in the $8^{\text {th }}$ Edition of the Field Checklist of Saskatchewan Birds published by Nature Saskatchewan in April 2002.

RED-THROATED LOON. 2nd record. 3 swimming near the east end of Echo Lake, May 6, 1995. The red throats were clearly seen (ML).

RED-NECKED GREBE. Status change. Now rarely seen. 
EARED GREBE. Early spring record -1, west end of Echo Lake, April 13, 1999 (RH).

PIED-BILLED GREBE. Winter record -1, in Qu'Appelle River at Fort Qu'Appelle (RH,CBC). Early spring record-1, northeast of Whitewood, April 5, 1998 (BM).

\section{AMERICAN WHITE PELICAN. Early} spring record - 60 , east end of Muscowpetung Reserve, April 7, 1996. Winter records -1 , near Lebret Bridge, Dec. 1 until Dec. 22, 1997 (RH,CBC); 1, west end of Echo Lake, Dec. 18, and 20, 1998 (LR, PB, and RH,CBC). It was reported that the bird was later found dead, and had only 1 wing.

\section{DOUBLE-CRESTED CORMORANT.} Early spring record - 4, west end of Echo Lake, April 11, 1999 (RH). Late winter record - 1, west of Lebret Bridge, Dec. 2, 1996 (RH). Breeding - Nesting in aspens on the south side of Round Lake, in recent years. In the 1970s they nested east of Round Lake (BM).

GREAT BLUE HERON. Tie for early spring date -1, east of Katepwa Dam, April 4, 1997 (JM, PA). Winter records -1, Qu'Appelle River, east of Fort Qu'Appelle, Nov.9,1996 (RK); 1, Crooked Lake, Dec. 1992 (CBC); 1, found dead, north side of Qu'Appelle River near Fort Qu'Appelle, Jan. 29,1989 (ML).

GREAT EGRET. Recent records -1, along river east of Katepwa Lake, May 9,1987 (RH); 1, at Katepwa Dam, May 31, 1991 (RH); 2, Pipestone Valley south of Grenfell, April 25,1996, and May 3,1996 (BM, JP).

TUNDRA SWAN. Winter records- During CBC at Fort Qu'Appelle, 1992 and 1993; Crooked Lake, 1996; and Round Lake, 1998. Latest winter record - 1, east end of Katepwa Lake, early Feb.1997 (PA).

TRUMPETER SWAN. Status change Individuals and small groups have been seen and heard in the Fort Qu'Appelle area in fall, early winter, and spring from 1988 and on. This corresponds to their summer occurrence in Greenwater Park since 1986. Early fall record-12, at Bluebill Bay of Echo Lake, Oct.28, 1988 (RH). Late winter record-1, west end of Echo Lake, Jan.1,1992 (CBC, RH). Early spring record-4, Fort Qu'Appelle, March 25, 2000 (RH).

CANADA GOOSE. Status change. Now a common summer resident again. Winter records-A few stragglers or wounded birds remain until nearly Christmas normally. When there is little snow many stay until early January. (Thousands stayed until early Jan. 1998, and in Jan. 2000, when 150 stayed throughout the winter near Fort Qu'Appelle) (RH).

GREATER WHITE-FRONTED GOOSE. Early spring record-50 (flying north and calling), Fort Qu'Appelle, March 23, 2000,(RH).

SNOW GOOSE. Early spring record-800 (of both white and blue phases), Fort Qu'Appelle, March 27, 2000 (RH). Late spring record-2, on slough south of Balcarres, May 21, 1998, (RH). Winter record-1 (blue phase), Fort Qu'Appelle, Dec. 12, until Dec.22, 1997, (CBC, RH). Status change - Now abundant in spring and fall migrations. Sometimes a thousand birds or more can be seen in one field at once.

ROSS' GOOSE. Recent records - In the winter of 1987-1988 one spent the winter with Harold Ross's tame geese (as if he knew it was Ross's place!) north of Fort Qu'Appelle, but a stray dog killed it in the spring. 1, at the west end of Echo Lake, April 12,1989 (Frank Brazier).

MALLARD. Recent overwintering Normally about 65 overwinter in the river between Echo and Pasqua Lakes. I suspect that they are hardy Mallards from the north rather than local ones. In the mild winter of 1999-2000 about 250 overwintered. 
AMERICAN BLACK DUCK. Recent record - 1, Qu'Appelle Valley, north of Whitewood, July 29,1993 (JP). Winter record - 1, Round Lake, Dec.,1999 (CBC).

GADWALL. Winter records - CBC recordsCrooked Lake, 1996 and 1997; Round Lake, 1997, and Fort Qu'Appelle, 1999.

GREEN-WINGED TEAL Early spring record - 6, Qu'Appelle River at Fort Qu'Appelle, April 1, 1997 (RH). Winter records-CBC records for Fort Qu'Appelle, Dec. 24, 1997, and Crooked Lake, Dec., 1999.

CINNAMON TEAL. Recent record -1 male, with a male Blue-winged Teal, in the Qu'Appelle River near Fort Qu'Appelle, May 9, 1991 (RH).

WOOD DUCK. Early spring record - 4, Round Lake area, April 14,1996 (JP). First winter record-2, Round Lake, Dec. 19,1998 (CBC).

RING-NECKED DUCK. Early spring record - 2, west of dam at Fort Qu'Appelle, March 13, 1995 (RH). Late winter record 1, Crooked Lake, Dec. 25, 1989 (CBC).

GREATER SCAUP. Recent records - 1 (seen with binoculars while flying, the long white wing stripe was clearly seen), Fort Qu'Appelle, Nov. 22, 1988 (RH); 2, Qu'Appelle River west of Echo Lake, Dec.2, 1989 (RH); 30, Fort Qu'Appelle, April 30, 1991 (RH).

LESSER SCAUP. Earliest spring record 4, Qu'Appelle River west of Echo Lake, March 26, 1992 (RH).

COMMON GOLDENEYE. Possible nesting - 1 female came out of a duck nest box on a pole, near Bluebill Bay, west of Fort Qu'Appelle, June 14, 1994 (RH).

BARROW'S GOLDENEYE. Recent records -2, Fort Qu'Appelle, Nov.29, 1991
(RH). 1 female (vertical forehead and decreased white in wingband clearly seen), Qu'Appelle River, west of Echo Lake, Dec. 22, 1993, until Jan.3, 1994 (CBC, RH, RK); 1 female with female Common Goldeneye, on sandbar near east end of Echo Lake, June 18, 1994 (RH); 1 pair, west of dam near Fort Qu'Appelle, April 12, 1997 (RH).

BUFFLEHEAD Winter records - CBC records -Fort Qu'Appelle, 1991, 1992, 1994, and 1996; Indian Head, 1994; Crooked Lake, 1996 and 1999; Round Lake, 1999. Latest winter record -1, Qu'Appelle River west of Echo Lake, Feb.15,1997 (RH, RK).

LONG-TAILED DUCK. Recent records -1 female, with flock of Ring-necked Ducks, in Qu'Appelle River near Lebret Bridge, Nov.2,1996 (L. Brass)(RH); 1, Pasqua Lake, Nov. 9, 1996 (RK); 1, east end of Mission Lake, Nov. 9, 1996 (RK). 4, Katepwa Lake, Dec.1, 1998 (JP, BM).

\#HARLEQUIN DUCK. New species - 1 female or immature, in Qu'Appelle River at Fort Qu'Appelle, Nov.13, 1991, until Dec. 14, 1991 (CBC, RH); 1 female, by Katepwa dam, Sept. 26, 1995 (N. Henderson).

BLACK SCOTER. Additional record -1 male, east end of Katepwa Lake, Dec.2, 1998 (RH).

WHITE-WINGED SCOTER. Late fall record -1 immature, Fort Qu'Appelle, Dec. 4, $1992(\mathrm{RH})$.

SURF SCOTER. Additional record - 1 female, east end of Echo Lake, Dec. 2, 1998 (RH).

RUDDY DUCK. Winter records- 1 male, in Qu'Appelle River, south east of Lebret, Dec. 6, 1995 (RH); 1 male, east end of Pasqua Lake, Dec. 7, 1997, until Jan. 5, 1998 (CBC, $\mathrm{RH})$.

HOODED MERGANSER. Early spring record - 1, Round and Crooked lakes area, 
April 12, 1997 (BM, JP). Late spring record -1 male, west end of Echo Lake, May 29, 1989 (RH). First summer record- 1 female, Qu'Appelle Valley, north of Whitewood, July 29, 1993 (JP). Late winter record - 1 female, west of Echo Lake, Jan. 3, 1999 (CBC, RH).

\section{COMMON MERGANSER. Breeding} records - 1 female and 10 young, in Qu'Appelle River east of number 9 highway, 1994; other family groups seen between 1994 and 2000 (BM).

RED-BREASTED MERGANSER. Early spring record - 1 female, Fort Qu'Appelle, March 21, 1999 (RH).

TURKEY VULTURE. Winter records-1, Crooked Lake, Dec. 30, 1993 (CBC); 1, Crooked Lake, Dec. 31, 1994 (CBC); Second earliest spring record - 2 along Kaposvar Creek, SE of Esterhazy, April 4, 2002 (Debbie Pask); Two nesting records young in old barn SE of Lipton, summer 2001 (Irvin Huber) and 2 eggs in granary in early May 2002, along Kaposvar Creek SE of Esterhzy (Debbie Pask).

*\# BLACK VULTURE. New species - 1, 1.5 $\mathrm{km}$ west of Fort Qu'A ppelle, hovering above hill-tops on south side of the valley, all black beneath, except for white patches on wingtips, short spread-out tail, May 25, 1992 (RH). First sighting for Saskatchewan? Sometimes immature Turkey Vultures are wrongly reported to be Black Vultures.

NORTHERN GOSHAWK. Latest spring record -1 flying northward, Fort Qu'Appelle, April 22, 1996 (RH).

SHARP-SHINNED HAWK. Winter record1, Indian Head, Dec. 30, 1988 (CBC).

COOPER'S HAWK. Winter record-1, Round Lake, Dec., 1996 (CBC).

RED-TAILED HAWK. Late Winter record1, Fort Qu'Appelle, Dec.22,1997 (D. Harman, CBC).
FERRUGINOUS HAWK. Recent records One or two per year seen in the west part of the area (RH). 1, $8 \mathrm{~km}$ north of Whitewood, May 22, 1997 (JP); 1, $9 \mathrm{~km}$ south of Whitewood, April 30, 2000 (JP).

GOLDEN EAGLE. Summer records-1, in the Qu'Appelle Valley north of Whitewood, July 16, 1994 (JP); also in the same area, 2 soaring, Aug.9, 1994 (BM); 2 soaring, Aug. 14, 1994 (BM).

BALD EAGLE. Late summer record - 2, at a dead cow, with 8 Turkey Vultures, also 2 Golden Eagles flying nearby, Qu'Appelle Valley east of number 9 highway, Aug. 14, 1994 (BM).

NORTHERN HARRIER. Winter record -1 , Indian Head, Dec. 27, 1988 (CBC).

OSPREY. Summer records -1, Marieval, June 14, 1990 (JP); 1, north shore of Echo Lake, Aug. 4, 2000 (RH).

GYRFALCON. Recent records-CBC records-1, Indian Head, Jan. 3, 1996; 1, gray phase, Fort Qu'Appelle, Dec. 17, 1999; 1 gray phase, Fort Qu'Appelle, Dec. 15, 2001.

AMERICAN KESTREL. Late fall record 1, Round Lake, Oct. 26, 1991 (JP). First winter record-1, Indian Head, Dec. 27, 1998 (CBC)

SHARP-TAILED GROUSE. Status change - These have become very scarce in the Fort $\mathrm{Qu}$ 'Appelle area in the past ten years.

GRAY PARTRIDGE. Status change - These have become very scarce in the Fort $\mathrm{Qu}$ 'Appelle area in the past ten years.

\#WILD TURKEY. New species. Introduced a few km north of Pasqua Lake in 1986. About 20 were running wild in the area in January, 1989. In 1986, 6 were also released near Rocanville. Sightings- 1, Round Lake, Sept. 1989 (JP); 2, Fort Qu'Appelle, Dec. 15 and 17, 1991 (CBC); 1, Fort Qu'Appelle, 
Dec., 1992 (CBC). Introduced Wild Turkeys and pheasants only exist for a few years in our area until they are extirpated.

YELLOW RAIL. Early spring record- 2 heard, Lebret Marsh, May 15, 1992 (RH).

AMERICAN COOT. Early spring record1, April 4, 1990, Fort Qu'Appelle (RH).

SEMIPALMATED PLOVER. Late fall record - 2, east shore of Echo Lake ( $\mathrm{N}$. Henderson, D. Hjertas, RH).

KILLDEER. Winter record-1, Crooked Lake, Dec. 1997 (CBC).

COMMON SNIPE. First winter record- 1 , Along Qu'Appelle River, east of Pasqua Lake, Dec. 5, 1998 (RH).

SOLITARY SANDPIPER. Early spring record-1, Fort Qu'Appelle, April 24, 1989 (RH).

GREATER YELLOWLEGS. Early spring record-3, Lipton, April 9,1991 (RH).

DUNLIN. Early spring record- 1, $8 \mathrm{~km}$ south of Whitewood, May 4, 1996 (JP).

SHORT-BILLED DOWITCHER. Early spring record- $4,8 \mathrm{~km}$ south of Whitewood, May 4, 1996 (JP).

LONG-BILLED DOWITCHER. Early spring record-10, Whitewood, April 22, 1990 (JP).

BUFF-BREASTED SANDPIPER. Recent record - 5, near a flock of Golden Plovers, shore of "Balcarres Slough" south of Balcarres, May 21, 1998 (RH).

HUDSONIAN GODWIT. Early spring record-13, Whitewood, April 28,1990 (JP).

PARASITIC JAEGER. Second record - 1 , among hundreds of Ring-billed Gulls, east end of Echo Lake, Sept. 30, 1995 (M.Belcher, RH).

GLAUCOUS GULL. Additional records 8 adults (large white gulls with no black on wing-tips, and a distinctly lower call), flying south of Echo Lake, April 15, 1995 (RH); 1 immature, east end of Echo Lake, May 9, 1998 (RH); 1 immature, flying along south shore of Echo Lake, May 20, 1999 (RH); 1 immature, flying east of Echo Lake, Dec. 1, 1997 (RH); 1 immature, flying south of the valley, about $20 \mathrm{~km}$ west of the area covered by M. Callin, June 6, 2000 (LR,PB,RH).

*ICELAND GULL. Third record -1 immature (light brown colour with no white rump, black beak, and pink legs), flying at east end of Echo Lake, Dec. 17, 1987 (CBC, $\mathrm{RH}$ ).

HERRING GULL. New status - common spring and fall migrant, with immature birds sometimes remaining all summer. Early spring record-1, Fort Qu'Appelle, April 1, 1988, and April 1, 1992 (RH). Late winter record-1, east end of Katepwa Lake, Dec. 11, 1999 (RH, RK).

THAYER'S GULL. Status change -Regular in small numbers in spring migration, rare in fall migration. Early spring record-1, Fort Qu'Appelle, March 25, 2000 (RH). Fall date- east end of Echo Lake, Nov. 19,1994 (RH).

CALIFORNIA GULL. Early spring record3, Fort Qu'Appelle, April 1, 1989 (RH).

RING-BILLED GULL. Early spring recordFort Qu'Appelle, March 24, 2000 (RH).

\#MEW GULL. New species -1, standing on ice near the east end of Echo Lake beside a Herring Gull, (less than half the size of the Herring Gull, legs brighter yellow than a Ring-billed Gull, when the wing was raised it showed a black tip with very prominent white patches near the apex, the black did not extend up along the fore-edge of the wing as clearly as in a Ring-billed Gull, dull- 
coloured bill with no band), April 13, 1989 , (RH); 8 (as in previous sighting, but bills all yellow, with no black markings, the small size of their heads were noted), on sandbar near southeast corner of Echo Lake, at about $100 \mathrm{~m}$ in bright sunlight, Aug 6,1994 (RH); 1, flying at about $30 \mathrm{~m}$, southeast corner of Echo Lake, Aug. 16,1994 (RH).

BONAPARTE'S GULL. Early spring record- 8, Fort Qu'Appelle, April 19, 1985 (RH). Late fall record-8, Fort Qu'Appelle, Nov. 28, 1987 (RH).

\#BLACK-LEGGED KITTIWAKE. New species - 1, Heil Lake, southeast of Lemberg, Oct. 26, 1990 (photographed by D. Rowell, confirmed by RK) (B. Bordass, D. Rowell, J. McKen, LR, N. McKen, PB). This is the second record of this species for Saskatchewan. ${ }^{7}$

COMMON TERN. Early spring record -1 , Fort Qu'Appelle, April 19, 1985 (RH).

\#ARCTIC TERN. New species - Seen near the east end of Echo Lake on 2, May 3, 1988; 3, May 7, 1988; 2 adults and 1 immature, May 29,1989; 1, May 14, 1990; 1, May 18, 1991; 1, May 13, 1992; 1, May 22, 1996 (RH). On all of these occasions the complete red beak was noticed. On one occasion the dirty white breast and short legs were noted. At one sighting, the nasal call was heard. Care must be taken in identifying terns with all red beaks in summer because some Common Terns lack the black tip on the beak that time of the year.

LEAST TERN. Second record -1, flying with Forster's Terns (smaller, no forks in the tail, but tail slightly notched, white forehead, black line through the eyes, black wing-tip, yellowish beak), near the dam at Fort Qu'Appelle, May 26, 1989 (RH).

CASPIAN TERN. Biggest flock- 8, flying low on cloudy day east of Balcarres, May 9 , 1992 (RH).
BLACK TERN. Late fall record-1, east of Pasqua Lake, Sept. 23, 2001 (RH).

MOURNING DOVE. Early spring record1, Fort Qu'Appelle, April 4, 1998 (RH).

BLACK-BILLED CUCKOO. Late fall record-1, B-Say-Tah, Sept. 19, 1999 (RH).

EASTERN SCREECH OWL. Additional records -1 (gray phase), photographed in a shed, Moosomin, Jan. 1992 (D. Gillich); 1 (gray phase), Whitewood, Feb. 14,1994 (JP); 1 (gray phase), struck by a car between Fort Qu'Appelle and Balcarres, March 8, 1994, Looked after for a week and then released (A. Gillich).

NORTHERN HAWK OWL. Additional winter records- 2, Round Lake, Dec., 1985 (D.Francis, CBC); 1, Fort Qu'Appelle, Dec. 9, 1990, (RH); 1, Fort Qu'Appelle, Dec.15, 1990 until March 9, 1991 (LR, RH, CBC); 1, Fort Qu'Appelle, Dec. 20, 1995 (B. Luterbach); 1, Lebret, Dec. 21, 1995 until Jan. 1, 1996 (RH,CBC); 1, area of Round and Crooked Lakes, Dec. 7, 1996; 1, Edgeley, Feb. 7 and 8, 1997, (PA).

GREAT GRAY OWL. Recent records- 1, Whitewood, Feb.15,1997 (BM,JP); 1, Broadview, Dec.23, 2000 (CBC); 1, Whitewood, Dec.31, 2000 (CBC); 1, Broadview, Jan. 2001 (D.Weidl).

LONG-EARED OWL. 2nd winter record-1, in a spruce tree, south side of Mission Lake, Dec. 18, 1993 (D. Rowell, E. Cochrane, LR, CBC).

COMMON NIGHTHAWK. Status change - Seen uncommonly in migration in recent years. Summer records -Several seen and heard in late June and early July, 2001 near Tantallon and Fort Esperance (RH). Nesting record-One egg on flat rock on south facing prairie hillside, north of Fort Esperance, June 30, 2001 (RH). 
RUBY-THROATED HUMMINGBIRD. Early spring records- 1, Fort Qu'Appelle, April 22, 2000 (+19 C.) (J. Derkatch); 1, Fort Qu'Appelle, May 2, 2000 (M. Isfan).

*\#BLACK-CHINNED HUMMINGBIRD. New species -1 , at a feeder near Whitewood, May 20, 1996 (BM). A photo of it was sent to RK. He said that it could be this species, so it is still unconfirmed.

BELTED KINGFISHER. Early spring record- 1, Wolseley, April 4, 1992 (RH). Additional winter records-1, Fort Qu'Appelle, near the dam (it lived in a culvert), Nov.26, 1988 until Dec.26,1988 (CBC) (LR), and (RH); 1, Crooked Lake, Dec.21, 1998 (CBC).

NORTHERN FLICKER. Winter recordsSeen on Fort Qu'Appelle CBC 1991, 1999, 2000, and 2001; 1, Whitewood, Dec.23,1994 until March 1, 1995, (JP).

PILEATED WOODPECKER. Additional summer records-1, Qu'Appelle Valley, north of Whitewood on June 27, 1993, July 18,1996 and Aug.8,1997 (JP); 1 heard, Fort Esperance, June 29, $2001(\mathrm{RH})$.

LEWIS' WOODPECKER. Recent record 1 (dull red face noted, all dark with no white as it flew away with undulating woodpecker flight), north edge of Fort Qu'Appelle, Dec. 16, 1995 (BB, CBC, JM and PB).

WESTERN KINGBIRD. Late fall record1, Fort Qu'Appelle, Sept. 6, 1991 (RH).

GREAT CRESTED FLYCATCHER. Early spring record-1, B-Say-Tah, May 17, 2000 (RH).

EASTERN PHOEBE. Early spring record1, Camp McKay, Round Lake, April 13, 1991 (JP).

OLIVE-SIDED FLYCATCHER. Early spring record-2, Fort Qu'Appelle, April 24, 1997 (RH).
HORNED LARK. Status change - Still common in migration, but becoming an uncommon summer resident in the fields. Where we used to notice a dozen Horned Larks at a stop on the breeding birds survey south of Cupar every June, there are now 2 or 3 . This is probably due to the use of field sprays.

COMMON RAVEN. Status change - Now a year-round resident that is increasing annually. It has been regular here in winter since 1988, and in summer, since 1994. On November 19,1999 , I saw a flock of 20 ravens north of Lipton flying southwestward at tree-top level. Were these additional ravens moving in from the north for the winter? On December 15, 2001, a total of 27 were seen near Fort Qu'Appelle (CBC). Breeding record-1 adult in an aspen feeding a young bird, south side of Round Lake, summer of 2001 (BM).

\#MOUNTAIN CHICKADEE. New species -1 , at a feeder at Fort San, Dec. 17-19 (CBC) (E. Rak); 1, at a feeder, B-Say-Tah, Nov. 1991 (B. Whiting); 1, at a feeder, B-SayTah, late November, 1993 (B. Whiting).

BOREAL CHICKADEE. Largest flock- 6 (in flock with 2 Golden-crowned Kinglets), Fort Qu'Appelle, Dec.11, 1986 (RH).

WHITE-BREASTED NUTHATCH. First record of nest with eggs -Apparently the first report of sighting White-breasted Nuthatch eggs in a nest in Saskatchewan (C. S. Houston, pers. comm. May 2002). One nest hole was found about $2 \mathrm{~m}$ up in a maple tree, in late April, 1998. The eggs were too deep in the heart of the tree to see them with a light and a mirror. Later young birds were heard in the nest (RH). On May 11, 1998, PB showed me where she had seen a Whitebreasted Nuthatch come out of a hole, about $5 \mathrm{~m}$ up in an ash tree in Fort Qu'Appelle. I saw what was probably the mother bird going in and out of the hole, so I climbed up with a ladder. The entrance was a knot hole. I shone a flashlight in, and saw the nest about 
thirty $\mathrm{cm}$ below the entrance. The nest was lined with unidentified white furry seeds. In the nest there were 2 dull white eggs that had some spots and streaks at the larger end.The following day I showed the nest to PA. At this time 3 eggs could be seen.

RED-BREASTED NUTHATCH. Change in winter status -Now a regular, but uncommon winter resident among evergreens. Flocks of from 8 to 10 were seen at Fort Qu'Appelle, in December, 2001 (RH); 14 were seen on Dec.15, 2001 (CBC).

BROWN CREEPER. Additional winter records - Before 1985, Manley Callin only reported 1 winter record for the area. There are now winter records for 1985, 1986, 1989 , 1991, 1992, 1996, 1997, 1998, and 2001.

WINTER WREN. Additional records -1 , Among trees near south shore of Echo Lake,Nov. 7, 8, and 9, 1993 (RH and V. Lamontagne); 1, in same area as the 1993 bird, Nov. 20, 1999 (V. Lamontagne).

\section{*\# CAROLINA WREN. New species - 1} wren, at feeder in Fort Qu'Appelle, Nov.25, 1997 (F. Pearpoint). It was larger than a House Wren, buffy underneath, with a pale line above the eye. She saw one at a time at the feeder, but so frequently that she thought that there may have been more than one bird. One came also to the feeder in December 1997 between Christmas and New Years Day. ${ }^{4}$ Carolina Wrens are noted for moving northward in the fall to colonize a new area.

SEDGE WREN. First fall record - 4, near Lebret Marsh, Sept. 24, 1997 (RH).

NORTHERN MOCKINGBIRD. Recent records -1 , west of the dam at Fort Qu'Appelle, May 22, 1999; 1, west of Fort Qu'Appelle, March 24, 2001 (B. Hooper, $\mathrm{RH})$; 1, in Qu'Appelle Valley, east of number 9 highway, July 13, 1995 (BM).

BROWN THRASHER. Early spring recordWhitewood, May 1, 1998 (BM).
HERMIT THRUSH. Additional spring record - 1 male heard singing, Whitewood, April 30, 1995 (JP).

MOUNTAIN BLUEBIRD. First winter records-1 male, Fort San Road, Dec. 20, and 29, 1986 (CBC, RH); 1 female, along Fort San Road, Dec. 13, and 16, 1998 (RH, R. Luterbach).

TOWNSEND'S SOLITAIRE. Additional winter records in 1995, 1996, and 1998. 1, west of Fort Qu'Appelle, Dec. 20, 1998 (RH,CBC), moving through scrub with a flock of Bohemian Waxwings. Did they lately join company, or did they move in from the northwest together?

RUBY-CROWNED KINGLET. Early spring record-1, Round Lake, April 13, 1991 (JP).

SPRAGUE'S PIPIT. Early spring record-1 heard, Fort Qu'Appelle, April 20,1991 (RH).

NORTHERN SHRIKE. Late spring record -9, Round Lake, April 20, 1995 (JP).

\#WHITE-EYED VIREO. New species - 1 , northeast of Balgonie, May 28, 1992 (R. Long); seen again May 30, 1992, photographed and recorded (RK, R. Long, and R. Ramage). First confirmed record for Saskatchewan.

PHILADELPHIA VIREO. Late summer records -1, Whitewood, Aug. 19, 1993 (JP); 1 adult male, west of Fort Qu'Appelle, July 30, 1998 (RH).

WARBLING VIREO. Early spring record1 heard, Fort Qu'Appelle, May 8, 1994 (RH).

\#GOLDEN-WINGED WARBLER. New species -1 male (the golden crown and shoulders and black throat were noticed), south side of Mission Lake, May 1991 (J. Connor). 
NASHVILLE WARBLER. First summer records -2 banded, Qu'Appelle Valley and number 9 highway, July 5, 1994, and July 27, 1994 (JP).

YELLOW-RUMPED WARBLER. Late fall record- 1, Fort Qu'Appelle, Nov. 9, 1996 (RK).

BLACKBURNIAN WARBLER. Recent record -1, Qu'Appelle Valley and number 9 highway, May 25, 1992 (JP).

OVENBIRD. Early spring record-2, Indian Head, May 10, 1992 (JP).

\#HOODED WARBLER. New species - 1 female banded, Qu'Appelle Valley north of Whitewood, July 3, 1995 (JP). ${ }^{6}$ Fourth record for Saskatchewan. ${ }^{7}$

BOBOLINK. Early spring records- 1 each day, Fort Qu'Appelle, May 1, 8, and 9, 1998 (RH).

WESTERN MEADOWLARK. Early spring record-1, Wapella, March 18, 1997 (JP).

YELLOW-HEADED BLACKBIRD. Late fall record - 1 male, Fort Qu'Appelle, Oct. 21, 1997 (RH).

\#BULLOCK'S ORIOLE. New species -1 immature male, at a bird feeder at Fort Qu'Appelle, where it had been seen for about 5 days, Oct.28, 1988 (A. Laing, E. Cockwill, K. Lindgren, LR, and RH).

RUSTY BLACKBIRD. Early spring record-10, Crooked Lake, April 8, 1990 (JP). Late spring record-43, Fort Qu'Appelle, May 1, 1997 (RH) (identified by listening to the song of the males).

\section{BREWER'S BLACKBIRD. Early spring} record-1, Whitewood, April 13, 1993 (JP). There are a number of reports of this species as winter records. These need to be accepted with caution, as Rusty Blackbirds lose most of their rusty colours by Christmas time, and can' easily be mistaken for Brewer's Blackbirds. Male Brewer's have slightly heavier beaks, and the females are lighter brown with dark eyes.

BROWN-HEADED COWBIRD. Winter records-3, Whitewood, Dec. 10, 1994 (JP); 2, Whitewood, Dec. 22, 1996 (JP). It is expected that December cowbirds would show some signs of immature plumage, and would have shorter beaks than other blackbirds. Adult cowbirds normally leave for the south in early July. The immatures that are raised by other birds have to find their way south later. Any reports of wintering cowbirds should be viewed very cautiously, because their foster parents are species that do not overwinter here. Our usual overwintering blackbirds are Rusty Blackbirds, and Red-winged Blackbirds (which sometimes stay in small numbers among cattle), and the very casual occurrence of the Common Grackle around bird feeders.

WESTERN TANAGER. Recent records -1 male and 1 female fed (along with Northern Orioles) on orange slices nailed to a tree at Fort Qu'Appelle, May 24 and 25, 1997 (LR, $\mathrm{PB}$, and $\mathrm{RH})^{1}$; 1 , northeast of Whitewood, June 18, 1995 (BM).

SCARLET TANAGER. Recent record -1 male flew by at close range, Echo Creek Valley, southwest of Fort Qu'Appelle, June 14, 1992 (RH).

NORTHERN CARDINAL. Recent records - On Nov. 30, 1992, B. and D. Sipple of Esterhazy reported that cardinals were seen at their feeder occasionally in the last few previous years; 1 female at a feeder in Fort Qu'Appelle, Dec. 1, 1998, until Feb. 21, 1999 (A. Isfan, PB, RH, RK, CBC).

ROSE-BREASTED GROSBEAK. Early spring records-1, at feeder, Whitewood, May 10, 1991 (JP); 2, Indian Head, May 10, 1992 (JP). 
BLACK-HEADED GROSBEAK. Recent records -1 female, south of Lebret Marsh, May 17, 1986 (LR, RH); 1 female, north shore of Katepwa Lake, May 17, 1986 (LR, and RH); 1, Fort Qu'Appelle, May 29, 1997 (ML).

HOUSE FINCH. Change in winter status Now a fairly common permanent resident in some of the towns.

PINE GROSBEAK. Summer straggler-1, Whitewood, Aug. 12, 1992 (JP).

PINE SISKIN. Winter status change - Since 1982 a few Pine Siskins have been present nearly every winter. Sometimes they are locally common.

AMERICAN GOLDFINCH. Early spring record (or did it overwinter?)-1 immature male, at feeder in Fort Qu'Appelle, April 4, 1994, (B. Bordass, PB).

RED CROSSBILL. Spring records - 2, at feeder in Fort Qu'Appelle, early April until June 1, 1991 (B. Bordass, PB).

WHITE-WINGED CROSSBILL. Late spring record -1 at feeder, Whitewood, April 21, 1995 (JP).

SPOTTED TOWHEE. Late winter record1, at feeder southwest of Fort Qu'Appelle, Nov. 22 until Dec. 26, 1993 (RH, CBC). Both the Eastern Towhee and the Spotted Towhee are now regular summer residents at Fort Qu'Appelle. Trevor Herriot believes he sees some evidence of interbreeding in the Katepwa area (Trevor Herriot, pers. comm. May 2002).

LARK BUNTING. Unusually large flock 30, Round Lake, May 28, 1992 (JP).

GRASSHOPPER SPARROW. Early spring record-1 seen and heard, on prairie north of Lebret Marsh, May 10, 1997 (PA, RH).
BAIRD'S SPARROW. Early spring record3 singing males, along dried up marsh, west of Fort Qu'Appelle, May 9, 1998 (RH).

LARK SPARROW. First fall date recorded -3, south of Fort Qu'Appelle, Aug. 11, 1987 (RH).

DARK-EYED JUNCO. Early spring record-2, Round Lake, March 12, 1995 (JP).

TREE SPARROW. Late spring record -1 , Fort Qu'Appelle, May 19, 1990 (LR).

\#FIELD SPARROW. New species -1, east of Katepwa Bridge, April 28, 1997 (PA).

HARRIS' SPARROW. Early spring record1, Fort Qu'Appelle, April 16, 2000 (RH). Winter records in 1985, 1987, 1991, 1992, 1993, 1994, and 1997.

WHITE-CROWNED SPARROW. Early spring record-1 singing, Fort Qu'Appelle, April 25, 1991 (RH). Winter records-1, Broadview, Dec. 1986 (CBC); 1 immature, Fort Qu'Appelle, Dec. 30, 1998 until Jan.3, 1999 (J. Armstrong, RH, CBC).

GOLDEN-CROWNED SPARROW. Recent record -1, Fort Qu'Appelle, May 19, 1990 (LR).

WHITE-THROATED

SPARROW. Additional winter records-5, Indian Head, Dec. 27, 1987 (CBC); 1, Broadview, Dec. 1990 (CBC); 1, Fort Qu'Appelle, Dec.31, 1998 (J. Armstrong, CBC).

LINCOLN'S SPARROW. Late fall record2, Round Lake, Nov.2, 1996 (JP). Winter record-1, Whitewood, Dec. 11 until Dec. 18, 1992 (JP).

SONG SPARROW. Additional winter records-Fort San, 1988; Katepwa Lake, 1993; and Crooked Lake, 1999.

LAPLAND LONGSPUR. Additional winter records-20, Whitewood, Feb. 22, 1994 (JP); 
15, Whitewood, Dec. 22, 1996, (CBC); 45, Whitewood, Jan.5, 1997 (BM, JP); 15, Fort Qu'Appelle, Dec. 19,1997 (RH,CBC).

\section{Acknowledgements}

I gratefully acknowledge the kind assistance of Stuart Houston and Robert Kreba in checking over this supplement and offering encouragement and advice.

1. BORDASS, Phyllis, 1998. The oriole returns. Blue Jay, Vol. 56, No.1, 34.

2. CALLIN, Manley, 1980. Birds of the Qu'Appelle. Special Publication No. 13, Saskatchewan Natural History Society.

3. HOOPER, Ronald R.,1993. Possible Saskatchewan sighting of Black Vulture. Blue Jay, Vol. 51, No.2, 105.
4. HOOPER, Ronald R., 1998. A Possible Carolina Wren. Blue Jay, Vol.56, No. 3, 195.

5. HOUSTON, C. Stuart, and Mary I., 1986. Additions to Callin's Birds of the Qu'Appelle. Blue Jay, Vol.44, No.2, 70-84.

6. POLLOCK, John, 1995. A Hooded Warbler record in the eastern Qu'Appelle Valley. Blue Jay, Vol. 53, No. 3, 176.

7. SMITH, A. R. 1996. Atlas of Saskatchewan Birds. Special Publication \#22. Saskatchewan Natural History Society.

\title{
SPEEDY MIGRATION:
}

\section{SASKATCHEWAN'S FIRST OSPREY SATELLITE TRANSMITTER}

\begin{abstract}
C. STUART HOUSTON, 863 University Drive, Saskatoon, SK S7N 0J8 and MARK MARTELL, The Raptor Center, University of Minnesota, 1920 Fitch Ave., St. Paul, MN 55108
\end{abstract}

On July 2, 2001, a 35 g solar-assisted satellite transmitter was applied to the back of a $1900 \mathrm{~g}$ adult female Osprey, at her nest pole beside the South Saskatchewan River east of Rosthern, SK. The transmitter provided multiple daily latitude and longitude readings through the Argos system (see www.argosinc.com for more details). The data were analyzed and mapped using ArcView (ESRI Inc. Redland, CA) GIS, and distances were calculated using Grinwich.

The Osprey fed her young on or near her nest until August 10. We presume this was the date for the second youngster to fledge, for she then began to cruise up and down the river, most commonly in a south-westerly direction from her nest pole. From August 30 through September 6, she perched along the river only $5 \mathrm{~km}$ north of Saskatoon, 57 $\mathrm{km}$ from her nest platform.

Her first migration flight of $283 \mathrm{~km}$ on September 7 took her to near Avonlea, Saskatchewan. On the second day, after a flight of $640 \mathrm{~km}$, she reached Rapid Creek in the Black Hills west of Rapid City, South Dakota. The third and fourth days' flights 